\title{
Heavy mineral variation in the deep sea sediment of southeastern Arabian Sea during the past $32 \mathrm{kyr}$
}

\author{
Vaseem Akaram, S S Das*, A K Rai and Gaurav Mishra \\ Department of Earth and Planetary Sciences, University of Allahabad, Allahabad 211 002, India. \\ ${ }^{*}$ Corresponding author.e-mail: siddharthasankardas.alld@gmail.com
}

The present study is based on heavy mineral assemblages (HM) of top 104-cm thick section of gravity core SK 221 (Lat. $8^{\circ} 7.12^{\prime} \mathrm{N}$; Long. $73^{\circ} 16.38^{\prime} \mathrm{E}$ and water depth $-2188 \mathrm{~m}$ ) located near the ChagosLaccadive Ridge in the southeastern Arabian Sea to evaluate the provenance and paleoenvironmental changes during the last $32 \mathrm{kyr}$. The biogenic carbonate, acid insoluble residue, magnetic susceptibility, total organic carbon (TOC) and clay based humidity index, i.e., kaolinite/illite ratio are also utilized to correlate with the above paleoenvironmental changes. Ilmenite, garnet, staurolite, pyroxenes, andalusite and zircon are the dominant HM with moderate to low ZTR (zircon-tourmaline-rutile) index indicating instability of the sediments and rapid erosion in the source region. The characteristic HM suggest their mixed sources from the basic igneous, gneisses/granites, high grade metamorphic rocks and sandstones occurring mainly in the western and southwestern India. The temporal variations of HM, AIR (acid insoluble residue), MS (magnetic susceptibility), biogenic carbonate and $\mathrm{C}_{\text {org }}$ (TOC) during preglacial and early Holocene suggest intensive weathering, erosion, and transportation of terrigenous detritus from continental region by fluvial processes and summer monsoon led high biogenic productivity, respectively. The convective mixing of waters due to intense winter monsoon resulted in very high biogenic carbonate content during the early stages of glacial period. The HM and associated proxies indicated that the winter monsoons of Heinrich (H3, H2, and H1) and Younger Dryas (YD) events and summer monsoons of Bølling/Allerød (BA) event were not strong enough to bring drastic changes in the above parameters.

\section{Introduction}

Heavy mineral (denser than $2.85 \mathrm{~g} / \mathrm{cm}^{3}$ ) analysis is a significant tool to interpret the provenance, transportation history of the sediments and are widely applied for fluvial (Tiwari 2008; Joshua and Oyebanjo 2010), continental-beach-dune-shallow marine (Jayappa and Subramanya 1991; Hegde et al. 2006) and deep marine (Mc Knight 1974) arenaceous sediments. They are also very useful in evaluating pre-erosional weathering and tectonic history of the source terrain (Nechaev and Isphording 1993; Singh et al. 2004), exploration of minerals, and acquiring information on paleoenvironmental changes in marine sediments (Okay and Ergün 2005). Earlier, very few attempts have been made to study the heavy mineral assemblages (HM) in deep sea sediment for paleoenvironmental characterization (Nechaev and Isphording 1993). The processes that determine availability and size of heavy minerals are weathering, mechanical abrasion, hydraulic sorting and diagenesis (Morton and Hallsworth 1999). The changes in relative contributions of different source rocks and the intensity of the earlier four processes provide a compositional indication within the HM. The diagenetic effects on recent heavy minerals deposited in marine basin are considered

Keywords. Heavy minerals; Arabian Sea; Holocene; western India; provenance; paleoenvironment; glacial; preglacial. 
to be insignificant and therefore the provenance of different minerals can be identified.

The deposition of sediment in the Arabian Sea can be from a number of sources, i.e., dust originated from Arabia, fluvial detritus from the Indian subcontinent and Somalia (Das et al. 2013; Ishfaq et al. 2013). Based on the chemical composition of the sediments it is suggested that sediments may also be derived by submarine weathering of Carlsberg Ridge (Shankar et al. 1987). The supply of terrigenous material to the Arabian Sea is strongly linked to the intensity of monsoon (Haake et al. 1993; Ishfaq et al. 2013). In the eastern Arabian Sea, sediments deposited are mainly transported by fluvial processes (Paropkari 1990), whereas, in the western Arabian Sea they are mainly transported by aeolian processes (Krissek and Clemens 1991; Das et al. 2008). In the northern Arabian Sea both the fluvial as well as aeolian processes play important roles in sediment contribution (Naidu 1991). There is comprehensive information available with regard to the heavy minerals and placer deposits from the continental shelf and beaches of western coast of India (Mallik et al. 1987; Hegde et al. 2006; Nayak et al. 2012). Jayaraju (2004) studied the distribution patterns of heavy minerals along the southern tip of India. In this study, we describe the variation of HM from the deep marine sediments of the southeastern Arabian Sea and its relation to provenance and paleoenvironmental changes during the past 32 kyr.

\section{Materials and methods}

\subsection{Location, sampling and age of core}

A 5.5-m long gravity core (SK-221) was recovered from the southeastern region of Arabian Sea (figure 1) near Chagos-Laccadive Ridge during ORV Sagar Kanya cruise 221 from a water depth $2188 \mathrm{~m}$ at $8^{\circ} 7.12^{\prime} \mathrm{N}$ and $73^{\circ} 16.38^{\prime} \mathrm{E}$. This study is based on the samples collected from top $104 \mathrm{~cm}$ of the core. The sediment was subsampled at 1.0 $\mathrm{cm}$ intervals from $0-52 \mathrm{~cm}$ of the core and at 3.0 $\mathrm{cm}$ intervals for the rest. The samples for the magnetic susceptibility (MS) and total organic carbon (TOC) analyses were taken at $1 \mathrm{~cm}$ intervals. The clay-based humidity index, kaolinite/illite ration was taken from Das et al. (2013). The age model is based on the three AMS ${ }^{14} \mathrm{C}$ dates in planktonic foraminifer samples separated from the depths 0-1, 50-51, and 100-102 cm (Das et al. 2013). The average sedimentation rate for the core was $\sim 3.6$ $\mathrm{cm} / \mathrm{kyr}$ over the period of study.

\subsection{Separation of heavy minerals}

The measured bulk sediment samples were oven dried at $50^{\circ} \mathrm{C}$ and decalcified with $20 \%$ hydrochloric acid. The dried residue was treated with $30 \%$ hydrogen peroxide to remove the organic matter. The acid-insoluble residue (AIR) was calculated by subtracting the organic and carbonates percentages from the total. The sand was isolated

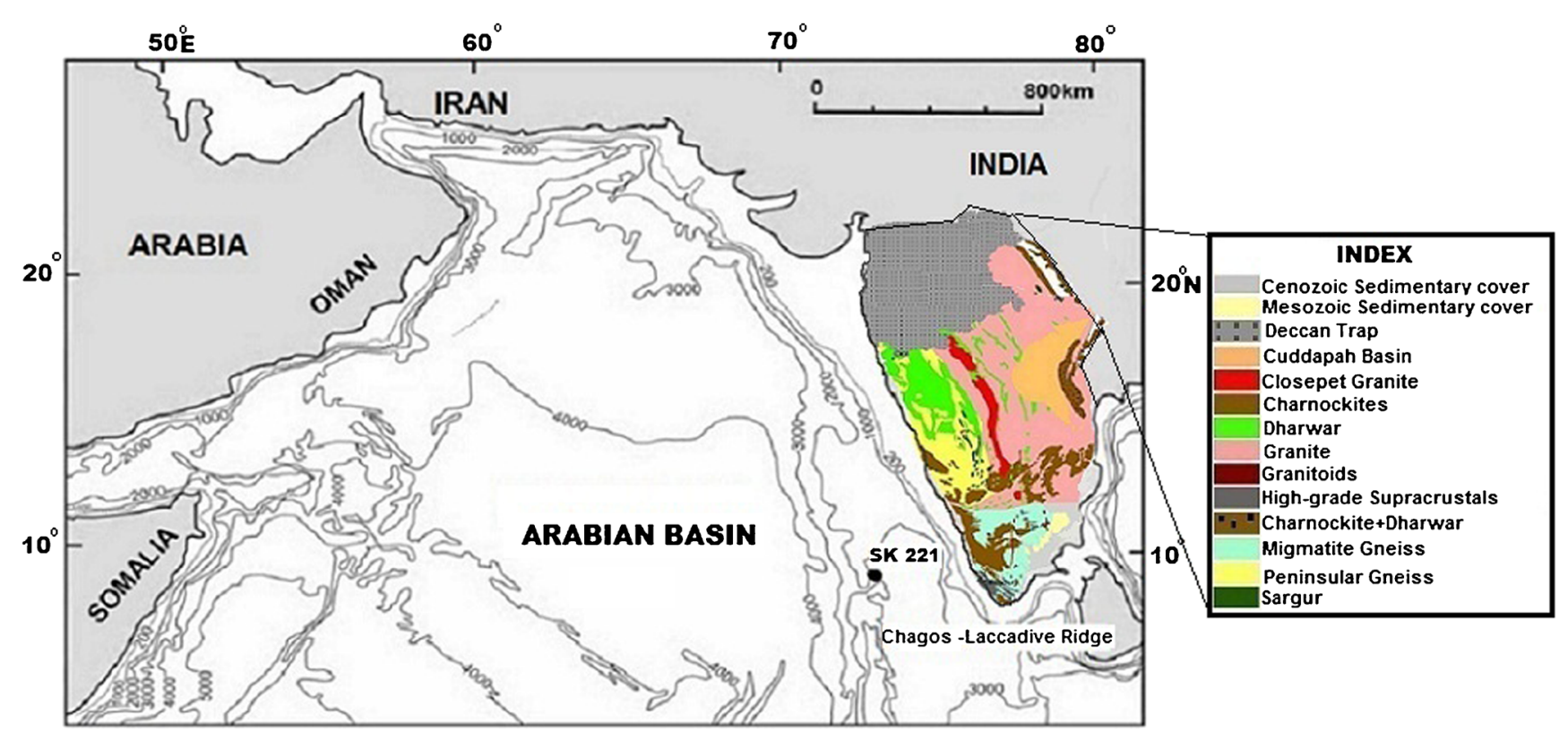

Figure 1. A map showing the location of core site SK-221 in southeastern Arabian Sea with bathymetric contours (redrawn after Debrabant et al. 1991) and various geological units of southwestern India (redrawn after Ramakrishnan and Vaidyanadhan 2008). 
from mud by sieving the AIR samples through a $63 \mu \mathrm{m}$ ASTM mesh. The sand sized grains from each sample were mounted onto a glass slide with araldite and viewed using an optical petrological microscope. Each heavy mineral could be identified based on the standard optical characteristics like colour, shape, and appearance. For each sample, all the heavy mineral grains (opaques and nonopaques) were counted by point counting method. The abundance of each non-opaque mineral was calculated as a percentage of the total grains counted for each sample. The zircon-tourmaline rutile (ZTR) index, a measurement for the sediment maturity as proposed by Hubert (1962) has also been calculated. To minimize the inaccuracies associated with the sample mounting procedures, identical sample preparation and quantification methods were followed.

\subsection{Measurement of MS and TOC}

The MS of dried sediment samples was calculated using the Bartington MS-2 magnetic susceptibility meter linked to an MS2B dual frequency sensor $(465$ and $4650 \mathrm{~Hz}$ ). The samples were air dried and packed in small plastic cylindrical pots (10 $\left.\mathrm{cm}^{3}\right)$. The MS meter was first calibrated with the given pots (blank run). The following magnetic parameters were measured: (a) low frequency $\chi_{\mathrm{lf}}$
$(465 \mathrm{~Hz}),(\mathrm{b})$ high frequency $\chi_{\mathrm{hf}}(4650 \mathrm{~Hz})$, and (c) frequency dependent susceptibility $\left(\chi_{\mathrm{fd}} \%\right)$ was determined using the formula: $\chi_{\mathrm{fd}} \%=\left(\chi_{\mathrm{lf}}-\chi_{\mathrm{hf}}\right) /$ $\chi_{\mathrm{lf}} \times 100$ (Mullins and Tite 1973). MS were measured for each sample as the mean of five repeat measurements with low and high frequency settings and presented as mass specific values in $10^{-8} \mathrm{~m}^{3} / \mathrm{kg}$ SI units. The mass specific MS value is approximately proportional to the concentration of ferromagnetic minerals within the samples and, in general, is an expression of the detrital input and subsequent dilutions by dia- and other paramagnetic minerals. The MS value increases as the concentration of magnetic materials in the sediment increase. While the frequency dependent MS indicates the presence of viscous grains lying in the stable domain/superparamagnetic boundary and their delayed response to the magnetizing field (Kumar et al. 2005).

The TOC content of 100 samples from this core section was estimated by titration method (Gaudette et al. 1974).

\section{Results}

\subsection{Biogenic carbonate, AIR, TOC and MS}

Table 1 shows the range and average of the previously studied parameters. Downcore variations

Table 1. Data range and average values of the studied parameters and minerals.

\begin{tabular}{|c|c|c|c|c|c|c|}
\hline \multirow{2}{*}{$\begin{array}{l}\text { Various parameters and } \\
\text { minerals studied }\end{array}$} & \multicolumn{2}{|c|}{ Holocene } & \multicolumn{2}{|c|}{ Glacial } & \multicolumn{2}{|c|}{ Preglacial } \\
\hline & Range & $\overline{\mathrm{Av}}$ & Range & $\overline{\mathrm{Av}}$ & Range & $\overline{\mathrm{Av}}$. \\
\hline Biogenic carbonate $(\%)$ & $68-81$ & 78 & $66-86$ & 76 & $68-82$ & 76 \\
\hline Acid insoluble residue (\%) & $17-31$ & 21 & $13-33$ & 23 & $17-31$ & 24 \\
\hline Total organic carbon $(\%)$ & $0.22-2.39$ & 1.14 & $0.07-1.69$ & 0.51 & $0.10-1.20$ & 0.41 \\
\hline Magnetic susceptibility (SI units) & $1.5-5.6$ & 3.1 & $1.2-6.0$ & 3.6 & $2.6-4.4$ & 3.5 \\
\hline Frequency dependant susceptibility & $8.1-40.5$ & 21.9 & $1.6-38.5$ & 14.6 & $1.6-13.8$ & 5.1 \\
\hline Kaolinite/illite ratio & $0.32-1.62$ & 1.03 & $0.27-1.40$ & 0.72 & $0.91-1.49$ & 1.15 \\
\hline Total number of heavy minerals counted & $4-190$ & 42 & $2-98$ & 45 & $11-92$ & 51 \\
\hline Opaque minerals (nos) & $0-144$ & 24 & $0-85$ & 30 & $1-70$ & 33 \\
\hline Non-opaque minerals (nos) & $3-51$ & 17 & $2-36$ & 12 & $1-42$ & 18 \\
\hline ZTR index (\%) & $0-100$ & 14 & $0-67$ & 32 & $0-100$ & 38 \\
\hline \multicolumn{7}{|l|}{ Non-opaque minerals } \\
\hline Staurolite $(\%)$ & $0-50$ & 9 & $0-25$ & 7 & $0-31$ & 8 \\
\hline Garnet (\%) & $0-55$ & 13 & $0-50$ & 7 & $0-14$ & 5 \\
\hline Pyroxene (\%) & $0-57$ & 14 & $0-36$ & 4 & $0-36$ & 8 \\
\hline Zircon (\%) & $0-17$ & 2.1 & $0-7$ & 2 & $0-14$ & 1.8 \\
\hline Rutile (\%) & $0-11$ & 1.4 & $0-29$ & 8.2 & $0-23$ & 7.3 \\
\hline Andalusite (\%) & $0-9$ & 0.6 & $0-15$ & 2 & $0-27$ & 6.5 \\
\hline Kyanite (\%) & $0-28$ & 3.2 & $0-14$ & 1.2 & $0-7$ & 0.6 \\
\hline Chlorite (\%) & $0-32$ & 4.8 & $0-25$ & 1 & 0 & 0 \\
\hline Monazite (\%) & 0 & 0 & $0-50$ & 2.8 & $0-18$ & 1.5 \\
\hline Apatite (\%) & 0 & 0 & $0-50$ & 3.1 & $0-9$ & 0.9 \\
\hline $\begin{array}{l}\text { Hornblende, tremolite, actinolite, epidote, } \\
\text { sillimanite, tourmaline and biotite }\end{array}$ & \multicolumn{6}{|c|}{ Each $<1 \%$} \\
\hline
\end{tabular}


of biogenic carbonate and AIR in core are shown in figure $2(\mathrm{a}, \mathrm{b})$. The carbonate content $(66-86 \%$, av. $77 \%$ ) shows distinct fluctuations with high $\mathrm{CaCO}_{3}$ content during the major stages of preglacial (68-82\%, av. $76 \%)$, glacial (22-19 ka) (78-86\%, av. 81\%), and Holocene periods (68-81\%, av. $78 \%$; table 1). However, biogenic carbonate
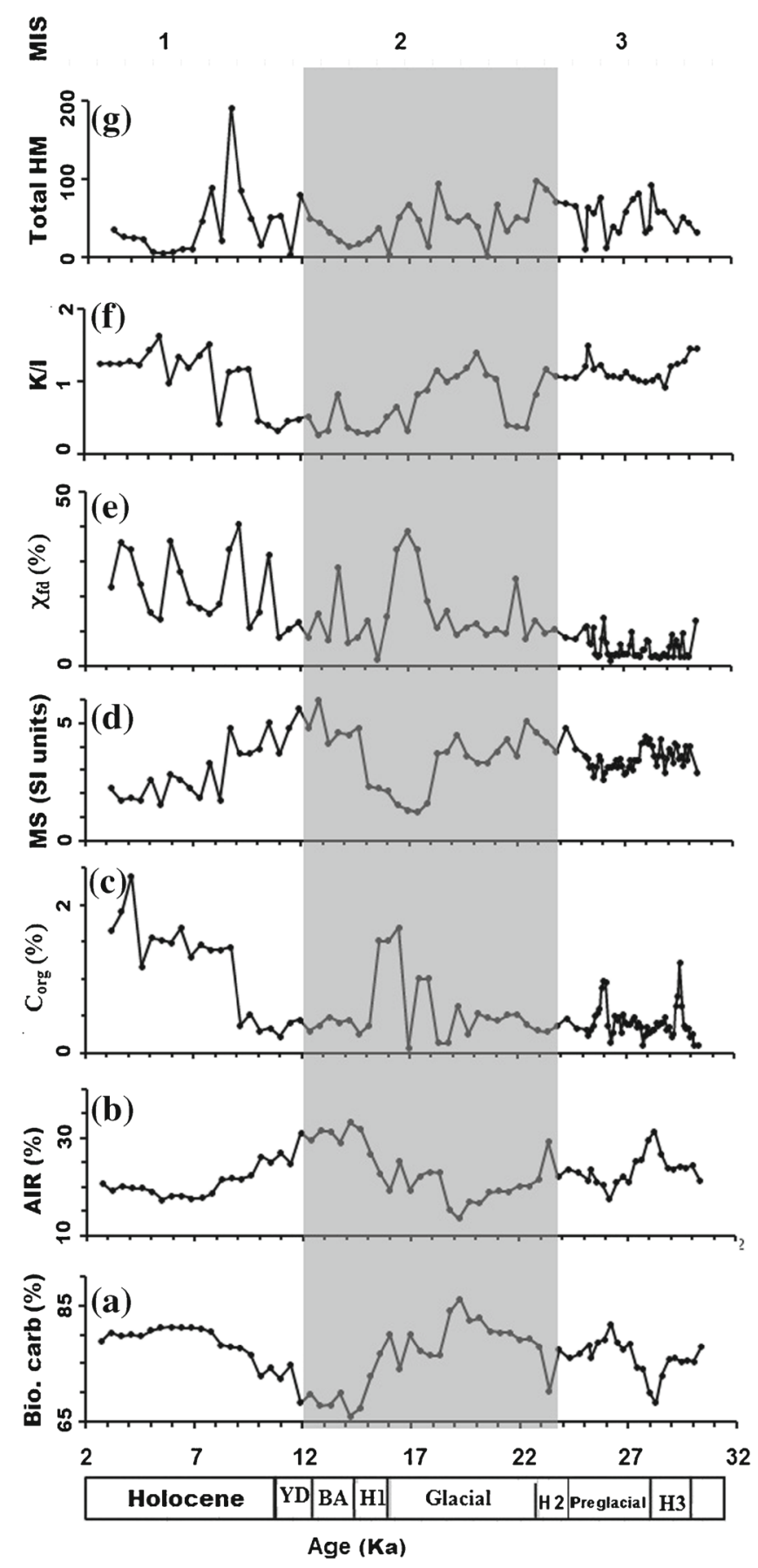

Figure 2. Temporal variations of biogenic carbonate, AIR, TOC (Corg), MS, frequency dependant susceptibility $\left(\chi_{\mathrm{fd}} \%\right)$, kaolinite/illite $(\mathrm{K} / \mathrm{I})$ ratio, and total heavy minerals (THM). MIS: marine isotopic stages; H1, H2 and H3: Heinrich events; YD: Younger Dryas; BA: Bølling/Allerød event. Ages of MIS (marine isotopic stages) boundaries after Imbrie et al. (1984). content remained comparatively low during Heinrich Events H3 (68-75\%, av. 73\%), H2 (70-76\%, av. $75 \%)$ and $\mathrm{H} 1 \quad(67-80 \%, 74 \%)$ and Younger Dryas Event (YD) (68-74\%, av. 70\%) (figure 2a). The AIR content varied between 13 and $33 \%$ (av. $22 \%$ ) and showed inverse relationship with biogenic carbonate content (figure $2 \mathrm{~b}$ ). The TOC ranged between 0.07 and $2.4 \%$ with an average of $0.6 \%$ and showed almost similar pattern to that of biogenic carbonate content (figure 2c). MS values are mostly $<5$ SI units and positively correlated with the AIR contents (figure 2d). The MS remained moderately high during H3 (2.9-4.4 SI units, av. 3.9 SI units), H2 (3.8-4.8 SI units, av. 4.2 SI units) and YD events (3.7-6 SI units, av. 5 SI units). The high frequency dependent MS values coincide with the low MS values of samples (figure 2e).

\subsection{Clay-based humidity index (kaolinite/illite ratio)}

The clay-based humidity index kaolinite/illite $(\mathrm{K} / \mathrm{I})$ ratio was calculated for samples from the relative abundance of each mineral (Das et al. 2013). The ratio (K/I) varied between 0.27 and 1.62 with an average of 0.95 . It showed relatively higher values during preglacial (av. 1.2), parts of glacial (20-17 ka) (av. 1.1), and Holocene periods (av. 1.03) (figure 2f). It remained significantly low (0.4) during $\sim 22 \mathrm{ka}$ and 17-10 ka (av. 0.4). The ratio remained moderately high during $\mathrm{H} 3$ (av. 1.2) and H2 (av. 1) and low during H1 (av. 0.3) and YD (av. 0.3) events. A minor increase (av. 0.5) in the ratio was recorded during the Bølling/Allerød (BA) event.

\subsection{Heavy mineral analysis}

The sand sized $(0.063-2 \mathrm{~mm})$ particles studied under the microscope showed plenty of broken tests of siliceous microfossils (Radiolaria and diatoms) and chert, quartz, feldspar, with some opaque (two types of minerals) and non-opaque heavy minerals (17 types of minerals). Although only a relatively small number (2-190 nos, av. 46) of heavy mineral grains were recovered, certain trends were also noted. The mineral grains were dominantly subangular to angular with few subrounded to rounded grains. The total heavy mineral content showed very high (22-190 nos, av. 80) values during 10-7 ka, early parts of Holocene (figure $2 \mathrm{~g}$ ). During the major parts of glacial (2-98 nos, av. 45) and preglacial stages (11-92 nos, av. 51) the number of heavy mineral grains remained moderately high with some fluctuations. The heavy mineral contribution remained moderately high during $\mathrm{H} 3$ (31-92 nos, av. 51), H2 (66-98 nos, av. 78) and 
YD (4-79 nos, av. 46) and low during H1 (4-38 nos, av.19) events. The heavy mineral contribution showed an increasing trend during the BA event.

Ilmenite was recorded as the dominant opaque mineral with few grains of magnetite. The dominant non-opaque heavy minerals were garnet (colourless, brown and reddish), staurolite (golden yellow), pyroxenes (pale green to off white), rutile (deep red), zircon (colourless and pale pink) and
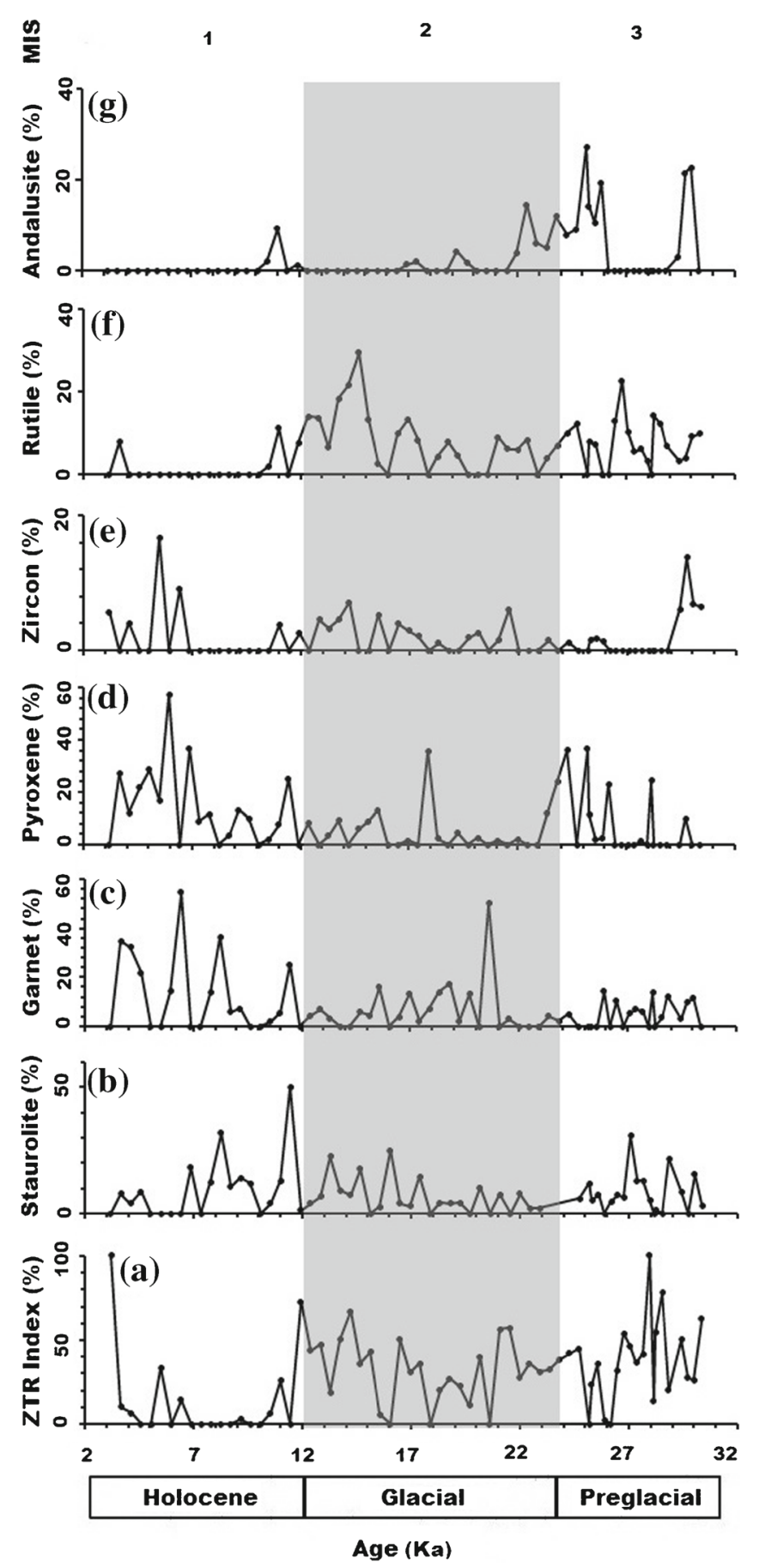

Figure 3. Temporal variations of ZTR index and various non-opaque heavy minerals. Ages of MIS (marine isotopic stages) boundaries after Imbrie et al. (1984). andalusite (colourless to grayish-white). Other important but minor heavy minerals recorded were hornblende (green to light yellow), tremolite, actinolite, kyanite (colourless and light blue), sillimanite, biotite (brown and green), chlorite (green), apatite (colourless), monazite (brownish red), epidote (lemon yellow) and tourmaline (pale yellow, greenish yellow, blue, brown and pink). The ZTR index of majority of the samples remained either around $60 \%$ or much lower than this value (figure 3a). It was significantly low (av. 14\%) during most of the Holocene. Staurolite showed almost a continuous contribution pattern till the early Holocene, but decreased steadily during the later parts of Holocene (figure $3 \mathrm{~b}$ ). Holocene was characterized by relatively higher occurrence of garnet $(0-55 \%$, av. $13 \%)$ and pyroxene (0-57\%, av. $14 \%)$ (figure $3 \mathrm{c}$ and $\mathrm{d}$ ). Zircon contribution was significantly low/absent between 29-22 ka and early Holocene, whereas rutile was nearly absent during Holocene (figure $3 \mathrm{e}, \mathrm{f}$ ). Andalusite showed contributions only during parts of preglacial and early parts of glacial stages (figure $3 \mathrm{~g}$ ).

\section{Discussion}

\subsection{Provenance discrimination}

Provenance of arenaceous sediments can be determined by the total compositional suite, cumulative properties of specific detrital fraction and specific varietal features of the single detrital components (Bahlburg and Floyd 1999). Some of the heavy minerals are diagnostic (e.g., garnet and staurolite high rank metamorphic rock; apatiteacid igneous rock; ilmenite and magnetite-basic igneous rock) of a particular source rock type (Pettijohn et al. 1973). Others are more ubiquitous and may occur nearly in all the possible types of parent rocks. The ZTR index for most of the studied samples lies below 60\% indicating moderate to low sediment maturity which indicates rapid erosion in the source region and short transportation (Hubert 1962). It also indicates moderate to high relief in the source region. Occasionally, high $(>60 \%)$ values of ZTR index during the preglacial stage indicates derivation of sediment from ancient sandstone and/or recycled sediment.

The heavy minerals are dominantly angular to subangular, but few grains are subrounded to rounded. The angular to subangular mineral grains indicate their derivation from the primary igneous and metamorphic rocks. Besides, the rounded to subrounded grains are indicative of sedimentary and meta-sedimentary source (Garzanti and Andó 2007). 
The non-opaque heavy mineral assemblage consists of ultrastable minerals (e.g., zircon, tourmaline and rutile); moderately stable minerals (e.g., garnet, staurolite, kyanite, sillimanite, pyroxenes), and unstable minerals (e.g., hornblende, apatite, and andalusite) (stability classification after Pettijohn et al. 1973). The presence of garnet predominantly reflects the metamorphic source rocks. Colourless garnet is assumed to have been derived from metapelitic schists, reddish garnet from ultrabasic igneous rocks and ultra-high pressure metamorphic rocks, and brownish garnet from igneous and metamorphic rocks, particularly crystalline gneisses and schists (Deer et al. 1982). Staurolite may have been derived from medium to high grade metamorphic rocks such as schists and gneisses. Although staurolite is typically developed in rocks with rich alumina, it can also occur in some metamorphosed impure carbonate rocks and sandstones. Pyroxenes are mostly derived from ultrabasic-basic igneous rocks and are also an important mineral constituent of charnockites and granulites. The presence of rutile indicates that sialic igneous and metamorphic rocks contributed this mineral. Rutile is present in small amounts in certain amphibolites. The colourless zircon indicates its derivation from plutonic igneous rocks, especially those rich in sodium content (Jayaraju 2004). It may also be derived from metasedimentary rocks. The presence of hornblende can be interpreted to indicate both the high grade metamorphic and plutonic acid igneous rocks in the source area.

The kyanite-sillimanite in this sediment indicates the presence of kyanite-sillimanite bearing high grade metapelitic rocks available in the source region. The presence of staurolite, kyanite and garnet suggests a provenance comprising metamorphic rocks of green schist to amphibolite facies. The andalusite is derived from contact aureoles in argillaceous sedimentary rocks formed due to the intrusion of igneous in to it. The colour of tourmaline varies widely, various shades of green and yellow, blue, brown and pink. Pale green to yellowish green tourmaline is derived from pneumatolytic rocks, pegmatites, schists and gneisses; brown and green tourmaline from granitic rocks and blue tourmaline from pegmatite injected metamorphic terrain (Hazarika 1984). Apatite also indicates its derivation from granitic and pegmatitic rocks. Tremolite and actinolite are likely to be derived from low grade regionally metamorphosed ultrabasic and carbonate rocks. Monazite could be derived from granitic and pegmatitic rocks, syenites and dolomitic marbles. Epidote is indicative of crystalline metamorphic rock or highly altered igneous rock. Chlorite is commonly derived from low rank metamorphic rocks. The presence of ilmenite and magnetite indicate basic igneous source rocks.

Based on this analysis, the source rocks - heavy minerals found in this site may be grouped into four assemblages:

(i) garnet-staurolite-kyanite-andalusitehornblende-monazite: medium to high-grade metamorphic (schistose, charnockites, granulites) rocks;

(ii) zircon-rutile-epidote-monazite-tourmalineapatite: granites/gneisses, pegmatites;

(iii) pyroxenes-hornblende-ilmenite-magnetite: basic igneous rocks/amphibolites;

(iv) tremolite-actinolite: metamorphosed calc-silicate rocks.

The potential terrigenous sediment and its transport pathways in the Arabian Sea indicate several source areas, e.g., eolian dust originated from Arabian peninsula, fluvial detritus from the Indian subcontinent and Somalia. The sediment contribution is also possible due to submarine weathering of sea floor. Based on the chemical composition of the sediment, Shankar et al. (1987) suggested that Arabian Sea sediments are also derived by submarine weathering of Carlsberg Ridge. The Indus River, which drains large areas north of the IndusTsangpo suture zone and cuts rapidly exhuming crustal zones at the western Himalayan syntaxes, carry heavy minerals, hornblende-dominated sediment along with epidote, garnet, and pyroxenes (Garzanti and Andó 2007). Prins et al. (2000) indicated that the southern and southeastern boundaries of Indus fan are extended up to Carlsberg and Chagos-Laccadive ridges, respectively. However, the influence of Himalayan sediment transported by the Indus River is largely restricted to the north of Gulf of Kutch due to the macrotidal currents in these zones acting as barriers for long shore sediment transport to the south (Nair et al. 1982). The monsoon winds deliver more than 100 million tons of dust to the Arabian Sea every year (Sirocko and Sarnthein 1989). This eolian dust contribution is an important mechanism for western Arabian Sea (Rao and Rao 1995). The dominant presence of subangular to angular sand sized heavy minerals indicate a short sediment transport distance. This implies that sediment at this site is mainly contributed from the nearby Indian peninsular region. The numerous small and medium sized streams and rivers originated from the steep slopes of Western Ghats are draining products of weathering into the eastern Arabian Sea (discharge $\sim 100 \mathrm{~km}^{3}$ annually). Moreover, the Western Ghats mountain range with its elevations up to $1000 \mathrm{~m}$ play a major role in controlling the rainfall intensity (annual rainfall intensity $>300 \mathrm{~mm}$ ) over the western coastal areas. 
The disintegration and decomposition of various rocks occurring in the western and southwestern India and floor of the ocean must have contributed to the above-mentioned heavy minerals at this site. Heavy minerals detached from the host rocks are ultimately brought to the coastal and deep sea regions by fluvial, eolian and marine currents. The northern part of western India consists of Western Ghats down to Dharwar and Ratnagiri, is composed of the Deccan Trap, the central part consists of Dharwar schist belt, and southern part composed of Precambrian gneisses, granites, khondalites and charnockites (figure 1). The Warkali Formation consists of ferruginous sandstone which is exposed along the coast of Kerala, southwest India (Raha et al. 1983). These geological units with their associated rocks must have played a major role in the contribution of the heavy minerals (for details of rock types and mineralogy, see Ramakrishnan and Vaidyanadhan 2008). Almost identical heavy mineral assemblages have been reported from various beaches in the southern tip and south-western India (Jayaraju 2004; Hegde et al. 2006). Based on clay mineral assemblages study of this site, Das et al. (2013) also indicated the above regions as dominant sources for sediments. Although few, the presence of rounded to subrounded heavy minerals indicate their derivation from the sedimentary source, e.g., Warkali Formation of Kerala and underwater sand of paleobeaches present along the coast of Kerala and Maharashtra (Mallik 1974; Raha et al. 1983; Shankar and Kharrbasi 1992).

\subsection{Paleoenvironmental implications}

The provenance and transport pathways of heavy minerals to the present site suggest that the climatic conditions that existed in the hinterland during late Quaternary controlled the weathering, erosion and heavy minerals contribution. The other factors that might have controlled their derivation are fluvial discharges, sea level changes and oceanic circulation. The climate also led to the erosion reactivation and reworking of the soils in the source region. Das et al. (2013) considered AIR as terrigenous matter, but on detailed investigation it is observed that the AIR consists of both terrigenous and non-terrigenous materials. They indicated that the terrigenous materials consist of quartz, feldspar, and clay minerals. The clay minerals are dominantly made up of illite, kaolinite and chlorite with minor quantities of smectite.

In this study, it is observed that heavy minerals contribution remained moderately high during parts of preglacial (av. 51 nos) and early stages of Holocene (av. 80 nos). During the same periods,
AIR (av. 25\%) and magnetic susceptibility of the samples also remained moderately high (av. 4 SI units) and biogenic carbonate content remained either moderately high (av. 78\%) or slowly increasing. The clay-based humidity index and organic carbon content also show similar patterns to that of biogenic carbonate. These observations indicate intensive weathering, erosion and transportation of terrigenous materials due to increased precipitation in the source region. This also causes terrigenous dilution of calcium carbonate at the site. The higher values of MS are also related to the higher terrigenous matter input (Kumar et al. 2005). It is also noticed that during same periods along with opaque minerals, the non-opaque minerals such as pyroxenes (8 and 14\%), staurolite ( 8 and $15 \%$ ) and clay minerals (chlorite, smectite and kaolinite) contributions were relatively high. Rao and Rao (1995) have indicated that the terrigenous sediments in the southwestern continental margin of India are predominantly river borne. The high calcium carbonate content during above periods also suggested enhanced marine biogenic productivity. Guptha et al. (2005) suggested that the biogenic productivity and supply of terrigenous matter to the Arabian Sea is strongly linked to the intensity of monsoon. Nair et al. (1989) suggested that the biogenic productivity is generally high in the Arabian Sea and $70-80 \%$ of the biogenic material is deposited during the summer monsoon period.

The high calcium carbonate (av. 81\%) and organic carbon (av. 0.7\%) contents during the early stages of glacial period (MIS 2) are attributed to stronger and colder winter monsoon winds which led to winter convective mixing. The deep mixing of surface waters induces an injection of nutrients into the euphotic layer leading to enhanced primary production (Duplessy 1982). Because of that the terrigenous supply from hinterland is not very high. However, the heavy mineral content, clay-based humidity index, and MS values were moderately high during this period. The kaolinite, chlorite and smectite were also moderately contributed during this period (Das et al. 2013). This may be due to the sea level fall and erosion of sediment from the exposed continental shelf by wind at the later stages of Pleistocene glaciation. These sediments were trapped on the shelf during highstand of sea level during the preglacial stage (Chodankar et al. 2004). The fluvial erosion and retreat of Western Ghats escarpment might have contributed some sediment to the deep sea (Kale and Shejwalkar 2007). Several researchers recorded increased productivity in eastern Arabian Sea during glacial climate (Banakar et al. 2005; Prabhu and Shankar 2005).

The high AIR (av. 30\%) and relatively low (av. $69 \%$ ) calcium carbonate contents along with low 
organic carbon (av. 0.4\%) and K/I ratios (av. 0.4) during the late glacial period suggest dry climatic condition and greater terrigenous dilution. The MS values (av. 4.4 SI units) were also moderately high during this period. But the total HM content (28 nos) was either low or reduced. The sea level during the last glacial period (LGP) was between 100 and $120 \mathrm{~m}$ below the present day level and rivers were debouching into the sea far away from the present day coastline (Narayana et al. 2009). This resulted in erosion of exposed continental shelf by fluvial and/or by winter winds. The former is considered unlikely since the summer monsoon during the glacial period was comparatively weaker. This must have resulted in weakening of the competency and capacity of sediment transportation by seasonal rivers which originated from the Western Ghats mountain. Hence, the intensified winter winds of the glacial period might have played a significant role in the derivation of fine grained terrigenous material from the continental region and its transportation to the eastern Arabian Sea.

Ishfaq et al. (2013) recorded less terrigenous input in the eastern Arabian Sea during the past $5 \mathrm{ka}$. In this study, there is no distinct change observed in the biogenic carbonate during the above period although humidity index shows a minor fall. The terrigenous input (av. 19\%) and MS values (av. 2 SI units) were low during this period. The total HM (av. 23 nos) contribution also remained low. This possibly indicates a fall in the intensity of summer monsoon led precipitation in the hinterland and less terrigenous erosion.

The contribution of total heavy minerals remained moderately high during H3 (av. 53 nos), H2 (av. 70 nos) and YD (av. 48 nos) and slightly low during H1 (av. 19 nos) events. The AIR and MS values were also in positive correlation with the total HM. The biogenic carbonate content was also moderate $(\sim 65 \%)$ during theses events. These implied that the winter monsoons of these events were not severe but were strong enough to cause moderate amount of biogenic precipitation in the sea and derivation of terrigenous material from the continents. Several researchers have recorded increased productivity in the eastern Arabian Sea whenever colder events persisted (Banakar et al. 2005; Prabhu and Shankar 2005). The BA event recorded slightly low (14-50 nos, av. 32 nos) but an increasing trend for total HM. However, the AIR (av. 31\%) and MS (av. 4.8 SI units) values recorded were very high during this period. Although, the biogenic carbonate content recorded was low (av. 68\%), the humidity index showed slightly high (av. 0.5) values during this period. The clay minerals kaolinite and smectite were contributed in higher amounts during this period (Das et al. 2013). All these observations collectively indicated that the summer monsoons were not very strong to enhance biogenic productivity in the sea but winter monsoon winds were sufficiently active to transport fine terrigenous clastics dominated by clay minerals from the continents.

The temporal variation of individual heavy minerals indicated that the provenance remained almost same throughout the study period. However, on closer examination of the garnet and pyroxene patterns indicated that the southern high grade metamorphic granulitic source rocks were slightly dominant (Madurai Granulitic Block, Kerala) over the northern granitic, gneissic and basic igneous rocks. This was perhaps due to the relatively increased weathering and erosion of southern rocks in comparison to the northern rocks. Sajinkumar et al. (2011) indicated high chemical index of alteration values of rocks (62-65) and soils (88-93) and associated mass wasting in the southern parts of Western Ghats consisting of Madurai Granulitic Block, Kerala. The presence of several paleobeaches (Mallik 1974; Shankar and Kharrbasi 1992) and occurrence of Miocene sedimentary source in Kerala coast might have also played some role in the development of such patterns of heavy minerals.

\section{Conclusions}

Records of HM variations from core SK-221 in the southeastern Arabian Sea offer a unique opportunity to evaluate the nature of provenance, transport history of deep sea sediments and paleoenvironmental changes during the last $32 \mathrm{kyr}$.

- The dominance of subangular to angular HM grains with moderate to low ZTR index $(\sim 60 \%)$ in most of the samples reflect instability of the sediments which is possibly due to the rapid erosion in the source region and reduced transportation of the sediments.

- The disintegration and decomposition of the basic igneous, granites/gneisses, high grade metamorphic rocks and sandstones occurring in the western and southwestern India must have contributed heavy minerals to the site.

- Increased weathering, erosion and transportation of terrigenous materials due to enhanced precipitation in the source region during preglacial and early Holocene stages result in relatively higher contributions of heavy minerals.

- The convective mixing of waters due to very strong, cold winter monsoon during early glacial stage significantly increased the biogenic productivity.

- Dry climatic condition during the late glacial period resulted in the erosion of fine grained 
clastics from continental region and exposed continental shelf by winds. This also caused terrigenous dilution in the sea.

- Moderately higher contribution of HM, higher values of AIR and MS along with moderate values of biogenic carbonate content during $\mathrm{H} 3$, $\mathrm{H} 2$ and YD events suggest that winter monsoons were not severe but strong enough to cause erosion of terrigenous materials from the continent and moderate amount of biogenic carbonate precipitation in the sea.

- The low values of total HM and biogenic carbonate content, increased values of AIR and MS along with slightly higher humidity index during the BA event suggest that relatively weaker summer monsoon could not increase the biogenic productivity whereas winter monsoon was strong enough to transport terrigenous clastics from the hinterland.

\section{Acknowledgements}

The authors gratefully acknowledge the Director, National Centre for Antarctic and Ocean Research, Goa for providing core samples for this study. Authors thank Mr. D D Pandey for assisting in drafting the figures. The authors are also thankful to two anonymous reviewers for their constructive comments, which helped to improve the quality of the paper.

\section{References}

Bahlburg H and Floyd P A 1999 Advanced techniques in provenance analysis of sedimentary rocks; Sedim. Geol. 124 1-220.

Banakar V K, Oba T, Chodankar A R, Kuramoto T, Yamamoto M and Minagawa M 2005 Monsoon related changes in sea surface productivity and water column denitrification in the eastern Arabian Sea during the last glacial cycle; Mar. Geol. 219 99-108.

Chodankar A R, Banakar V K and Oba T 2004 Past 100 kyr surface salinity gradient response in the eastern Arabian Sea to the summer monsoon variation recorded by $\partial^{18} \mathrm{O}$ of G. sacculifer; Global Planet. Change 47 135-142.

Das S S, Maurya A S, Pandey A C, Uday Bhan and Rai A K 2008 Influence of sediment source and monsoonal variations on the late Quaternary clay mineral assemblages at ODP site 728A, north-western Arabian Sea; Curr. Sci. 95(9) 1320-1326.

Das S S, Rai A K, Akaram V, Verma D, Pandey A C, Dutta K and Ravi Prasad G V 2013 Paleoenvironmental significance of clay mineral assemblages in the southeastern Arabian Sea during last 30 kyr; J. Earth Syst. Sci. 122 173-185.

Debrabant P, Krissek L, Bouquillon A and Chamley H 1991 Clay mineralogy of Neogene sediments of the western Arabian Sea: Mineral abundances and palaeoenvironmental implications; In: Proceedings ODP, Scientific Results, Leg117 (eds) Prell W L et al., College Station, TX, pp. 183-196.
Deer W A, Howie R A and Zussman J 1982 Rock-forming Minerals. Orthosilicates; IA London, Longman Group, $917 \mathrm{p}$.

Duplessy J C 1982 Glacial to interglacial contrast in the northern Indian Ocean; Nature 295 494-498.

Garzanti E and Andó S 2007 Heavy mineral concentration in modern sands: Implications for provenance interpretation; In: Heavy Minerals in Use (eds) Mange M and Wright D K, Dev. Sedimentol. 58 517-545.

Gaudette H E, Flight W R, Toner L and Folger D W 1974 An inexpensive titration method for the determination of organic carbon in recent sediments; J. Sedim. Petrol. 44 249-253.

Guptha M V S, Naidu P D, Haake B G and Schiebel R 2005 Carbonate and carbon fluctuations in the eastern Arabian Sea over 140 ka: Implications on productivity changes; Deep-Sea Res. II 2 1981-1993.

Haake B, Ittekkot V, Rixon T, Ramaswami V, Nair R R and Curry W B 1993 Seasonality and inter annual variability of particle fluxes to the deep Arabian Sea; Deep-Sea Res. I $401323-1344$.

Hazarika I M 1984 Significance of heavy mineral studies of the Upper Tertiary Tipam sandstones of the Kemeng foothills of Arunachal Himalaya; In: Sedimentary geology of the Himalaya (ed.) R A K Srivastava (New Delhi: Today and Tomorrow Publ.), 541.

Hegde V S, Shalini G and Gosavi Kanchanagouri D 2006 Provenance of heavy minerals with special reference to ilmenite of the Honnavar beach, central west coast of India; Curr. Sci. 91(5) 644-648.

Hubert J F 1962 A zircon-tourmaline-rutile maturity index and the interdependence of the composition of heavy mineral assemblages with the gross composition and texture of sandstones; J. Sedim. Petrol. 32 440-450.

Imbrie J, Hays B J D, Martinson D G, McIntyre A, Mix A C, Morley J J, Pisias N G, Prell W L and Shackleton N J 1984 The orbital theory of Pleistocene climate: Support from a revised chronology of the marine $\delta^{18} \mathrm{O}$ record; In: Milankovitch and Climate I (eds) Berger A, Imbrie J, Hays J, Kukla G and Saltzmn B, Dreidel Norwell Mass, pp. 269-305.

Ishfaq A M, Pattan J N, Matta V M and Banakar V K 2013 Variation of paleo-productivity and terrigenous input in the eastern Arabian Sea during the past $100 \mathrm{ka}$; J. Geol. Soc. India 81 647-654.

Jayappa K S and Subramanya K R 1991 A textural and mineralogical study of beach sands between Talapady and Surathkal, Karnataka; J. Geol Soc. India 37 151163.

Jayaraju N 2004 Controls on formation and distribution of heavy minerals along southern tip of India; J. Indian Geophys. Union 8 191-194.

Joshua E O and Oyebanjo O A 2010 Grain-size and heavy mineral analysis of River Osun sediments; Australian J. Basic Appl. Sci. 4 498-501.

Kale V S and Shejwalkar N 2007 Western Ghat escarpment evolution in the Deccan Basalt Province: Geomorphic observations based on DEM analysis; J. Geol. Soc. India $\mathbf{7 0}$ 459-473.

Krissek L A and Clemens S C 1991 Mineralogic variations in a Pleistocene high-resolution eolian record from the Owen Ridge, western Arabian Sea (Site 722): Implications for sediment source conditions and monsoon history; In: Proceedings of the Ocean Drilling Program, Scientific Results (eds) Prell W L and Niitsuma N, College Station,TX (Ocean Drilling Program) 117 197-213, doi: 10.2973/odp.proc.sr.117.183.1991.

Kumar A A, Rao V P, Patil S K, Kessarkar P M and Thamban M 2005 Rock magnetic records of the 
sediments of the eastern Arabian Sea: Evidence for late quaternary climatic change; Mar. Geol. 220 59-82.

Mallik T K 1974 Heavy mineral placers in the beaches and offshore areas - their nature, origin, economic potential and exploration; Indian Mineal. 28 39-46.

Mallik T K, Vasudevan V, Verghese A and Machado T 1987 The black sand placer deposits of Kerala beach, southwest India; Mar. Geol. 77 129-150.

Mc Knight B K 1974 Heavy mineral content of sediments from deep sea drill sites 259-263, eastern Indian Ocean; Initial Reports of the Deep Sea Drilling Project, vol. 27, pp. 523-533.

Morton A C and Hallsworth C R 1999 Processes controlling the composition of heavy mineral assemblages in sandstones; Sedim. Geol. 124 3-29.

Mullins C E and Tite M S 1973 Magnetic viscosity, quadrature susceptibility, and frequency dependence of susceptibility in single-domain assemblies of magnetite and maghemite; J. Geophys. Res. 78 804-809.

Naidu P D 1991 Glacial to interglacial contrasts in the calcium carbonate content and influence of Indus discharge in two eastern Arabian Sea cores; Palaeogeogr. Palaeoclimatol. Palaeoecol. 86 255-263.

Nair R R, Hashimi N H and Rao V P 1982 On the possibility of high velocity tidal streams as dynamic barriers to longshore sediment transport: Evidence from the continental shelf of the Gulf of Kutch, India; Mar. Geol. 47 $77-86$.

Nair R R, Ittekot V, Manganini S J, Ramswamy V, Haake B, Degens E T, Desai B N and Honjo S 1989 Increased particle flux to the deep ocean related to monsoons; Nature $338749-751$.

Narayana A C, Naidu P D, Shinu N, Nagabhushanam P and Sukhija B S 2009 Carbonate and organic carbon content changes over last $20 \mathrm{ka}$ in the southeastern Arabian Sea: Paleoceanographic implications; Quat. Int. 206 $72-77$.

Nayak B, Mohanty S and Bhattacharyya P 2012 Heavy minerals and the characters of ilmenite in the beach placer sands of Chavakkad-Ponnani, Kerala Coast, India; J. Geol. Soc. India 79 259-266.

Nechaev V P and Isphording W C 1993 Heavy-mineral assemblages of continental margin as indicators of plate-tectonic environments; J. Sedim. Petrol. 63 11101117.

Okay N and Ergün B 2005 Source of the basinal sediments in the Marmara Sea investigated using heavy minerals in the modern beach sands; Mar. Geol. 216 $1-15$.

Paropkari A L 1990 Geochemistry of sediments from the Mangalore-Cochin shelf and upper slope off southwest India: Geological and environmental factors controlling dispersal of elements; Chem. Geol. 81 99-119.

Pettijohn F J, Potter P E and Siever R 1973 Sand and Sandstones (New York: Springer-Verlag), 618p.

Prabhu C N and Shankar R 2005 Paleoproductivity of the eastern Arabian Sea during the past 200 ka: A multiproxy investigation; Deep-Sea Res. I 52 1994-2002.

Prins M A, Postma G, Cleveringa J A, Cramp A and Kenyon N H 2000 Controls on terrigenous sediment supply to the Arabian Sea during the late Quaternary: The Indus Fan; Mar. Geol. 169 326-349.

Raha P K, Sinha-Roy S and Rajendran C P 1983 A new approach to the lithostratigraphy of the Cenozoic sequence of Kerala; J. Geol. Soc. India 24 325-342.

Ramakrishnan M and Vaidyanadhan R 2008 Geology of India; Geol. Soc. India 1-2 994.

Rao V P and Rao B R 1995 Provenance and distribtuion of clay minerals in the sediments of the western continental shelf and slope of India; Cont. Shelf Res. 15 1757-1771.

Sajinkumar K S, Anbazhagan S, Pradeepkumar A P and Rani V R 2011 Weathering and landslide occurrences in parts of Western Ghats, Kerala; J. Geol. Soc. India 78 249-257.

Shankar R, Subarrao K V and Kolla V 1987 Geochemistry of surface sediments from the Arabian sea; Mar. Geol. 76 253-279.

Shankar R and Kharrbasi A R 1992 Sedimentological evidence for a paleobeach off Mangalore, west coast of India; J. Geol. Soc. India 40 241-252.

Singh B P, Pawar J S and Karlupia S K 2004 Dense mineral data from the north western Himalayan foreland sedimentary rocks and recent river sediments: Evaluation of the hinterland; J. Asian Earth Sci. 23 25-35.

Sirocko F and Sarnthein M 1989 Wind-borne deposits in the northwestern Indian Ocean: Record of Holocene sediments versus modern satellite data; In: Palaeoclimatology and Palaeometeorology: Modern and Past Patterns of Global Atmospheric Transport (eds) Leinen M and Sarnthein M, NATO ASI Series 282 401-433.

Tiwari G S 2008 Variation of heavy mineral in different lithofacies and geomorphic units of Ganga-Yamuna river near their confluence at Allahabad, U.P.; J. Geol. Soc. India 71 133-139. 